\title{
Associations between body mass index and foot joint pain in middle-aged and older women: a retrospective analysis of a longitudinal cohort
}

\author{
Anita Gay ${ }^{1,2 *}$, Catherine Bowen ${ }^{1,2}$, David Culliford ${ }^{2,3}$, Nigel Arden ${ }^{2,3}$ \\ From The College of Podiatry Annual Conference 2013: meeting abstracts \\ Liverpool, UK. 14-16 November 2013
}

\section{Objectives}

The objective of this study was to determine if a high body mass index (BMI) predicts foot joint pain (FJP) in middle-aged and older women over a 5-year period.

\section{Methods}

A retrospective, longitudinal, cohort study design was used to investigate the relationship between patient reported foot joint pain (FJP), body mass index (BMI) and age over time. Data has been prospectively collated (20 years) for women from the general population, the '1000 Women Study'. From a baseline of 1003 female participants, data from 639 women $(64 \%)$ were reviewed at years $(\mathrm{Y}) 10$ and 15.

\section{Results}

For year 10 and 15 (respectively) the median age was 61 years (57-67), 66 years (62-72); mean BMI $26.7 \mathrm{~kg} / \mathrm{m} 2$ ( \pm 4.6$), 27.2 \mathrm{~kg} / \mathrm{m} 2(4.8)$. BMI increased significantly from Y10 to Y15 ( $<<0.001)$. The FJP prevalence was $21.6 \%$ at year10 and $26.6 \%$ year 15 . The odds of having FJP after a 5 -year period increased by $4.9 \%$ for each BMI unit increase 5 years earlier (OR 1.049, 95\% CI $1.011-1.089 ; \mathrm{p}=0.012)$. This remained significant when adjusted for age (OR 1.049, 95\% CI 1.011-1.089; $\mathrm{p}=$ 0.012). A previous episode of FJP was a stronger predictor of having FJP 5 years later (OR 3.678, 95\% CI 2.465$5.489 ; \mathrm{p}<0.001)$.

\section{Conclusion}

This study confirms that a high BMI is likely to predict FJP in middle-aged women. These findings provide

${ }^{1}$ Faculty of Health Sciences, University of Southampton, Southampton, UK Full list of author information is available at the end of the article additional evidence to identify patients at risk of developing FJP, as well as evidence that foot health clinicians have a key role in public health interventions related to obesity.

\section{Authors' details}

'Faculty of Health Sciences, University of Southampton, Southampton, UK. ${ }^{2}$ Nuffield Department of Orthopaedics, Rheumatology and Musculoskeletal Sciences, University of Oxford, Oxford, UK. ${ }^{3}$ Faculty of Medicine, University of Southampton, Southampton, UK.

Published: 14 November 2014

doi:10.1186/1757-1146-7-S2-A4

Cite this article as: Gay et al:: Associations between body mass index and foot joint pain in middle-aged and older women: a retrospective analysis of a longitudinal cohort. Journal of Foot and Ankle Research 2014 7(Suppl 2):A4.

Submit your next manuscript to BioMed Central and take full advantage of:

- Convenient online submission

- Thorough peer review

- No space constraints or color figure charges

- Immediate publication on acceptance

- Inclusion in PubMed, CAS, Scopus and Google Scholar

- Research which is freely available for redistribution 